\title{
Spectrophotometric Determination of Catecholamines based on their Oxidation Reaction Followed by Coupling with 4-Aminobenzoic Acid
}

\author{
Tayyebeh Madrakian, * Abbas Afkhami, Lida Khalafi and Massoumeh Mohammadnejad \\ Department of Chemistry, Faculty of Science, Bu-Ali Sina University, Hamadan, Iran
}

\begin{abstract}
Um método espectrofotométrico simples e sensível para a determinação de dopamina, metildopa, levodopa e catecol, puros, em formulações farmacêuticas, e em água, é descrito. O método é baseado na reação de oxidação com periodato, seguida pelo acoplamento oxidativo com ácido 4-aminobenzóico em $\mathrm{pH} 4$, levando à formação de produtos coloridos. O gráfico de calibração foi linear no intervalo de $0,20-18,00 \mathrm{mg} \mathrm{L}^{-1}, 0,10-20,00 \mathrm{mg} \mathrm{L}^{-1}, 0,10-20,00 \mathrm{mg} \mathrm{L}^{-1} \mathrm{e}$ 0,10-13,00 $\mathrm{mg} \mathrm{L}^{-1}$ para dopamina, metildopa, levodopa e catecol, respectivamente. Dados analíticos para determinação do composto puro são apresentados juntamente com a aplicação do método proposto à análise das formulações farmacêuticas e amostras de água. Os resultados são favoravelmente comparados com métodos relatados.
\end{abstract}

A sensitive and simple spectrophotometric method for the determination of dopamine, methyldopa, levodopa and catechole in either pure form, pharmaceutical formulations and in water is described. The method is based on their oxidation reaction with periodate followed by oxidative coupling with 4-aminobenzoic acid at $\mathrm{pH} 4$ leading to the formation of colored products. The calibration graph was linear in the range of $0.20-18.00 \mathrm{mg} \mathrm{L}^{-1}, 0.10-20.00 \mathrm{mg} \mathrm{L}^{-1}, 0.10$ $20.00 \mathrm{mg} \mathrm{L}^{-1}$ and $0.10-13.00 \mathrm{mg} \mathrm{L}^{-1}$ for dopamine, methyldopa, levodopa and catechole, respectively. Analytical data for determination of the pure compound is presented together with the application of the proposed method to the analysis of some pharmaceutical formulations and water samples. The results compared favorably with reported methods.

Keywords: catechoamines, 4-aminobenzoic acid, pharmaceutical formulations

\section{Introduction}

Aromatic vic-diols are catechol derivatives in which 3 or 4 position is unsubstituted and these positions are sterically blocked. These derivatives are drugs and now, are widely used in the treatment of bornchail asthma, hypertension, Parkinson's disease myocardial infarction and cardiac surgery. ${ }^{1}$ The quantifying of catecholamines in physicological fluids has an importance in clinical chemistry as these biogenic amines serve as diagnostic marker molecules for a variety of metabolic and neurobiological disorders. ${ }^{2}$ The determination of plasma catecholamine levels have been proven to be a highly important for diagnosis, therapy and prognosis of cardiovascular diseases, catecholamine-secreting tumers arising from the chromaffin cells of the sympatoadrenalinal system such as neuroblastoma and pheochromocytoma, and active disorders. ${ }^{3}$ Pharmaceutical

*e-mail: madrakian@basu.ac.ir preparations containing these catecholamines have been available for many years. On the basis of this background, the determination of trace amounts of catecholamines is becoming increasingly important. In view of their importance, considerable work has been done on their detection and quantification. A number of methods have been reported for the determination of catecholamines by spectrofluorimetry, ${ }^{4}$ gas chromatography, ${ }^{5}$ capillary electrophoresis, ${ }^{6}$ chemiluminescence detection, ${ }^{7}$ high performance liquid chromatography (HPLC), ${ }^{8}$ radioimmunoassay ${ }^{9}$ and voltammmetric determination. ${ }^{10}$ Most of these methods lack the simplicity needed for routine analysis. Many spectrophotometric methods have been proposed. Some of them either lack sensitivity and specificity ${ }^{11,12}$ or require long heating ${ }^{13}$ or involve nonaqueous media. ${ }^{13}$ Some other spectrophotometric methods have very narrow limits of detection. ${ }^{14}$

Recently we investigated the electrooxidation of some catecholamines in the presence of 4-aminobenzoic acid at different $\mathrm{pH}$ values. ${ }^{15,16}$ The results indicated that the 
catecholamines were oxidized to their corresponding $o$-benzoquinone. In the absence of a nucleophile, the produced $o$-benzoquinone is attacked by the side chain amine group to form cyclized derivatives. But in the presence of 4-aminobenzoic acid, as a nucleophile, an adduct is produced by 1,4 (Michael) addition reaction of 4 -aminobenzoic acid on produced $o$-benzoquinone.

In this study a spectrophotometric method for the determination of the trace amounts of dopamine, methyldopa and levodopa has been introduced based on their oxidation reaction with periodate in the presence of 4 -aminobenzoic acid at $\mathrm{pH} 4$. The proposed method is simple, reliable and sensitive, and is suitable for the determination of trace quantities of dopamine, methyldopa and levodopa in pharmaceutical preparations, tap water and waste-water samples.

\section{Experimental}

\section{Apparatus}

A Perkin-Elmer 45 Lambda spectrophotometer with $1 \mathrm{~cm}$ quartz cells was used for recording spectra and absorbance measurements.

\section{Reagents}

All catecholamines, catechol, potassium periodate and 4-amiobenzoic acid were obtained from Merck and used without any purification. The structure of dopamine, methyldopa and levodopa are given in Scheme 1.

A stock solution of $0.01 \mathrm{~mol} \mathrm{~L}^{-1}$ periodate was prepared by dissolving $0.0023 \mathrm{~g}$ of $\mathrm{KIO}_{4}$ in water and diluting to the mark in a $100 \mathrm{~mL}$ volumetric flask. Dopamine, methyldopa, levodopa and catechol stock solutions (100 $\mathrm{mg} \mathrm{L}^{-1}$ ) were prepared in $\mathrm{pH} 4$ acetic acid-acetate buffer solution, and stored in a dark bottle in refrigerator. A 0.01 mol L-1 of 4-aminobenzoic acid was prepared by dissolving $0.00343 \mathrm{~g}$ of reagent in $100 \mathrm{~mL}$ volumetric flask. A 0.2 mol L-1 acetic acid-acetate buffer solution of $\mathrm{pH} 4$ was prepared from acetic acid and sodium acetate.
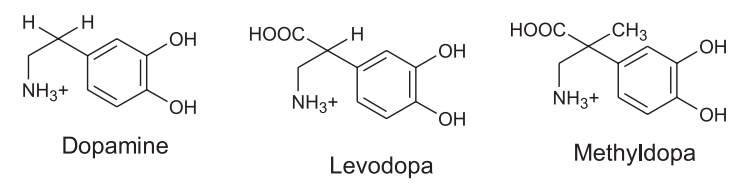

Scheme 1 .

\section{Procedure}

An aliquot of catecholamine solution was transferred into a $10 \mathrm{~mL}$ volumetric flask containing $1.0 \mathrm{~mL}$ of $\mathrm{pH}$ 4 acetate buffer solution and $0.4 \mathrm{~mL}$ of $0.01 \mathrm{~mol} \mathrm{~L}^{-1}$ 4-aminobenzoic acid. Then $0.3 \mathrm{~mL}$ of $0.01 \mathrm{~mol} \mathrm{~L}^{-1}$ periodate solution was added to the flask, and finally, the solution was diluted to the mark with water. The solution was allowed to stand for $10 \mathrm{~min}$ at room temperature and a portion of the solution was transferred into the cell to measure the absorbance at appropriate wavelength (see Table 1).

\section{Results and Discussion}

\section{Sequence of the reactions}

Figure 1 shows the spectra of dopamine, dopamine in the presence of periodate, and in the presence of periodate and 4-aminobenzoic acid at $\mathrm{pH}$ 4. The mechanism of the reaction is given in Scheme 2. The absorption spectrum of dopamine in the presence of periodate (Figure 1b) shows an absorption band with $\lambda_{\max }$ at $388 \mathrm{~nm}$ while that in the presence of periodate and 4-aminobenzoic acid (Figure 1c) shows an absorption band with $\lambda_{\text {max }}$ at $458 \mathrm{~nm}$. By oxidation of catecholamine with periodate the corresponding $o$-benzoquinone $(\mathbf{1 a})$ is produced. The absorption band with $\lambda_{\text {max }}$ at $388 \mathrm{~nm}$ belongs to 1a. In the presence of 4-aminobenzoic acid an adduct (3) is produced by 1,4 [Michael] addition reaction of 4-aminobenzoic acid on 1a. Then $\mathbf{3}$ is oxidized with periodate to $\mathbf{3 a}$. The absorption with $\lambda_{\max }$ at $458 \mathrm{~nm}$ belongs to $\mathbf{3 a}$.

The absorption spectra of the reaction mixture with time were also recorded. As Figure 2 shows the absorption band with the $\lambda_{\max }$ at $388 \mathrm{~nm}$ appeared immediately after

Table 1. Linear regression equations and precision for the determination of catecholamines

\begin{tabular}{|c|c|c|c|c|c|c|c|}
\hline Catecholamine & $\lambda_{\max } /(\mathrm{nm})$ & $\begin{array}{c}\text { Calibration } \\
\text { equation }^{\mathrm{a}}\end{array}$ & $\begin{array}{c}\text { Linear range / } \\
\left(\mathrm{mg} \mathrm{L}^{-1}\right)\end{array}$ & ${ }^{b} R^{2}$ & $\begin{array}{l}\text { Detection limit / } \\
\left(\mathrm{mg} \mathrm{L}^{-1}\right)\end{array}$ & $\mathrm{n}$ & $\begin{array}{c}\mathrm{RSD} /(\%) \\
(\mathrm{n}=7)\end{array}$ \\
\hline Dopamine & 458 & $0.0165 \mathrm{C}+0.0021$ & $0.20-18.00$ & 0.998 & 0.14 & 14 & 0.55 \\
\hline Methyldopa & 460 & $0.0169 \mathrm{C}+0.0035$ & $0.50-20.00$ & 0.999 & 0.20 & 11 & 0.92 \\
\hline Levodopa & 456 & $0.0163 \mathrm{C}+0.0038$ & $0.50-20.00$ & 0.998 & 0.20 & 13 & 0.85 \\
\hline catechole & 500 & $0.0529 \mathrm{C}+0.0040$ & $0.10-13.00$ & 0.997 & 0.09 & 10 & 0.65 \\
\hline
\end{tabular}

${ }^{\mathrm{a}} \mathrm{C}$ is the concentration analyte in $\mathrm{mg} \mathrm{L}^{-1}$. ${ }^{\mathrm{b}}$ Squared correlation coefficient. 


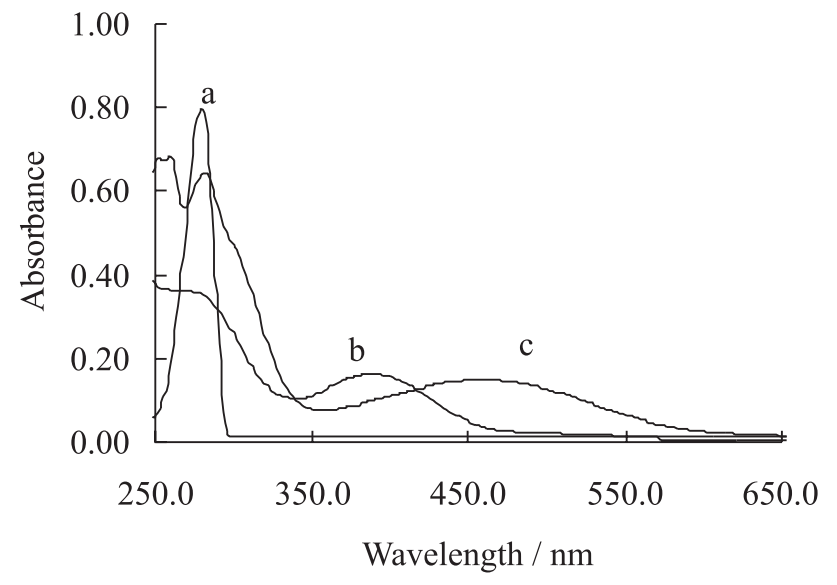

Figure 1. The absorption spectra for (a) $5.00 \mathrm{mg} \mathrm{L}^{-1}$ dopamine, (b) 5.00 $\mathrm{mg} \mathrm{L} \mathrm{L}^{-1}$ dopamine in the presence $3.0 \times 10^{-4} \mathrm{~mol} \mathrm{~L}^{-1}$ of periodate and (c) $5.00 \mathrm{mg} \mathrm{L}^{-1}$ dopamine in the presence $3.0 \times 10^{-4} \mathrm{~mol} \mathrm{~L}^{-1}$ of periodate and $4.0 \times 10^{-4} \mathrm{~mol} \mathrm{~L}^{-1}$ of 4-aminobenzoic acid. mixing of the reagents that indicates rapid oxidation of dopamine to dopaquinone. The absorbance of the solution decreased at $388 \mathrm{~nm}$ but increased at $458 \mathrm{~nm}$ with time. This decrease and increase that took place with a relatively slow rate is due to conversion of $\mathbf{1 a}$ to final 3a product by 1,4 [Michael] addition of 4-aminobenzoic acid on dopaquinone followed by oxidation of the produced adduct to final product by periodate. This indicates that conversion of $\mathbf{1 a}$ to $\mathbf{3 a}$ took place relatively slow. Absorption spectra for Levodopa and methyldopa in the presence of periodate and in the presence of periodate and 4-aminobenzoic acid at $\mathrm{pH} 4$ were also recorded (Figures 3 and 4). The $\lambda_{\max }$ for the absorption spectra of $o$-benzoquinones and final products correspond to levodopa and methyldopa was 396, 394, 460 and $456 \mathrm{~nm}$, respectively. The results were nearly the same as for dopamine except that the appearance and disappearance<smiles>[R]C([R])(CN)c1ccc(O)c(O)c1</smiles><smiles>CC(=O)c1ccc(N)cc1</smiles><smiles>[R]C([R])(CN)C1=CC(=O)C(=O)C=C1C([R])([R])CN</smiles><smiles>[R]C([R])(CN)C1=CC(=O)C(O)=CC1=Nc1ccc(C(=O)[O-])cc1</smiles><smiles>[R]C([R])(CN)C1=CC(=O)C(=O)C=C1C([R])([R])CN</smiles>

Overall Reaction<smiles>[R]C([R])(CN)c1ccc(O)c(O)c1</smiles>

1<smiles>[R]C([R])(CN)C1=CC(=O)C(O)=CC1=Nc1ccc(C(=O)O)cc1</smiles>

$\mathrm{R}^{1}=\mathrm{R}^{2}=\mathrm{H} \quad$ Dopamine

$\mathrm{R}^{1}=\mathrm{H}, \quad \mathrm{R}^{2}=\mathrm{COOH} \quad$ Levodopa

$\mathrm{R}^{1}=\mathrm{CH}_{3}, \quad \mathrm{R}^{2}=\mathrm{COOH} \quad$ Methyldopa 


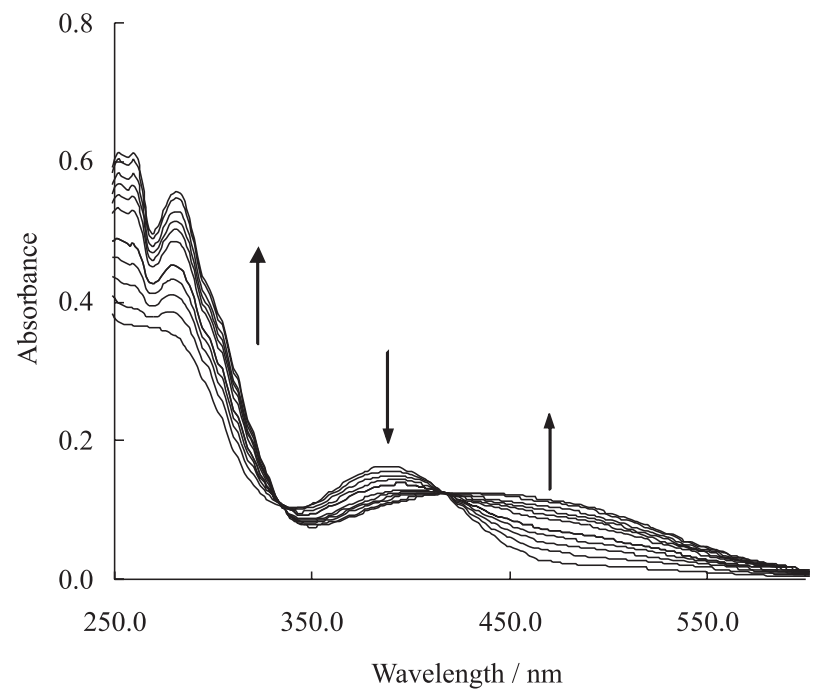

Figure 2. Absorption spectra for $5.00 \mathrm{mg} \mathrm{L}^{-1}$ dopamine in the presence of $3.0 \times 10^{-4} \mathrm{~mol} \mathrm{~L}^{-1}$ periodate ion and $4.0 \times 10^{-4} \mathrm{~mol} \mathrm{~L}^{-1} 4$-aminobenzoic acid with time at $\mathrm{pH} 4$. Time intervals, $2 \mathrm{~min}$.

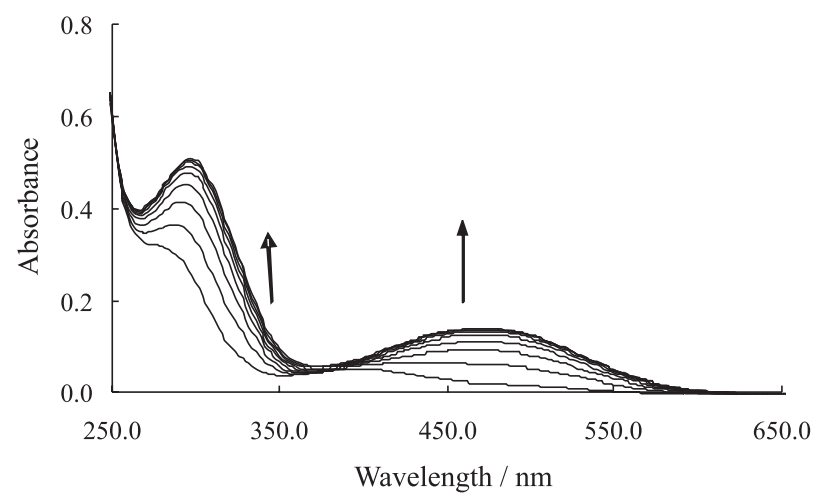

Figure 3. Absorption spectra for $5.00 \mathrm{mg} \mathrm{L}^{-1}$ levodopa in the presence of $3.0 \times 10^{-4} \mathrm{~mol} \mathrm{~L}^{-1}$ periodate ion and $4 \times 10^{-4} \mathrm{~mol} \mathrm{~L}^{-1} 4$-aminobenzoic acid with time at $\mathrm{pH} 4$. Time intervals, $2 \mathrm{~min}$.

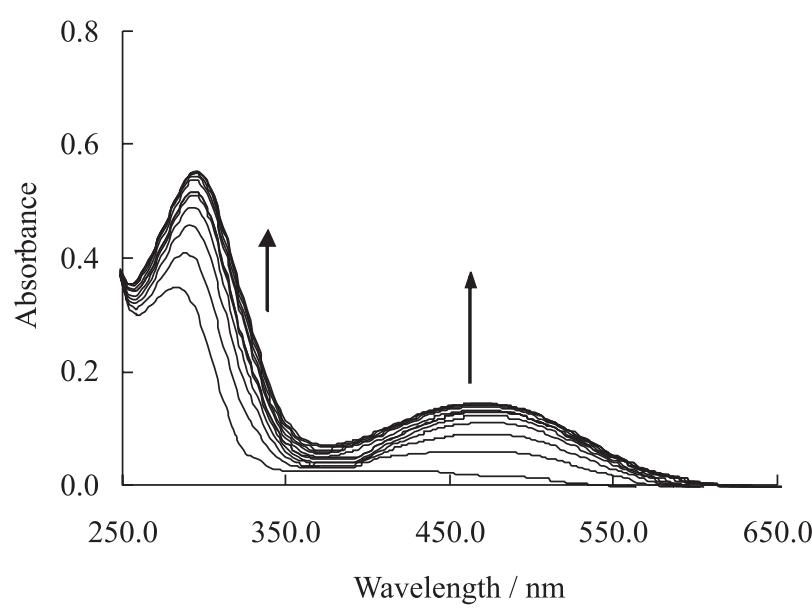

Figure 4. Absorption spectra for $5.00 \mathrm{mg} \mathrm{L}^{-1}$ methyldopa in the presence of $3.0 \times 10^{-4} \mathrm{~mol} \mathrm{~L}^{-1}$ periodate ion and $4.0 \times 10^{-4} \mathrm{~mol} \mathrm{~L}^{-1} 4$-aminobenzoic acid with time at $\mathrm{pH} 4$. Time intervals, 2 min.

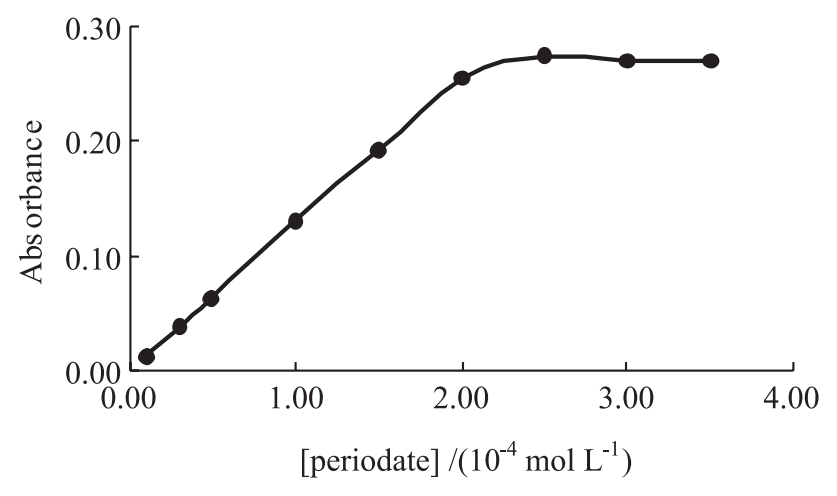

Figure 5. Effect of periodate concentration on the oxidation reaction of dopamine. Conditions: Dopamine, $5.00 \mathrm{mg} \mathrm{L}^{-1}$; 4-aminobenzoic acid, $4.0 \times 10^{-4} \mathrm{~mol} \mathrm{~L}^{-1} ; \mathrm{pH} 4$.

of corresponding $o$-benzoquinones produced by the oxidation of levodopa and methyldopa at 396 and 394 $\mathrm{nm}$, respectively, was not observed. This indicates higher activity of these o-benzoquinones relative to quinone.

\section{Effect of variables}

To take full advantages of the procedures, the reagent concentrations must be optimized. The parameters were optimized by setting all parameters constant and optimizing one each time. The effect of the parameters on the reactions of dopamine, methyldopa and levodopa determination were studied. As the results for the investigated catecholamines were nearly the same, only the results for dopamine as a typical catecholamine will be described.

The results of the investigation of electrochemical behavior of catecholamines in the presence of 4-aminobenzoic acid at different $\mathrm{pHs}^{16}$ showed that at $\mathrm{pH} 4.0$ no competition is observed between the intermolecular (reaction of 4-aminobenzoic acid with $o$-benzoquinone ring) and intramolecular (reaction of amine group with $o$-benzoquinone ring) Michael addition reactions for all the investigated catecholamines i.e. while the intermolecular reaction took place, intramolecular reaction did not take place at all. Therefore, we select $\mathrm{pH} 4.0$ for further investigations of the addition reaction of catecholamines with 4-aminobenzoic acid.

Table 2. The influence of various ions on the determination of $5.00 \mathrm{mg}$ $\mathrm{L}^{-1}$ catecholamines by the proposed method

\begin{tabular}{lccc}
\hline $\begin{array}{l}\text { Ions } \\
\text { added }\end{array}$ & $\begin{array}{c}\text { Tolerance } \\
\text { limit } /\left(\mathrm{mg} \mathrm{L}^{-1}\right)\end{array}$ & $\begin{array}{c}\text { Ions } \\
\text { added }\end{array}$ & $\begin{array}{c}\text { Tolerance } \\
\text { limit } /\left(\mathrm{mg} \mathrm{L}^{-1}\right)\end{array}$ \\
\hline $\mathrm{Na}^{+}$ & 5000 & $\mathrm{Cl}^{-}$ & 5000 \\
$\mathrm{~K}^{+}$ & 5000 & $\mathrm{NO}_{3}^{-}$ & 5000 \\
$\mathrm{Mg}^{2+}$ & 250 & $\mathrm{SO}_{4}^{2-}$ & 5000 \\
$\mathrm{Zn}^{2+}$ & 2500 & $\mathrm{PO}_{4}^{3-}$ & 500 \\
$\mathrm{Al}^{3+}$ & 100 & $\mathrm{HPO}_{4}^{2-}$ & 2500 \\
$\mathrm{~Pb}^{2+}$ & 10 & $\mathrm{CO}_{3}^{2-}$ & 500 \\
$\mathrm{Cu}^{2+}$ & 10 & $\mathrm{Glycine}^{2+}$ & 5000 \\
\hline
\end{tabular}




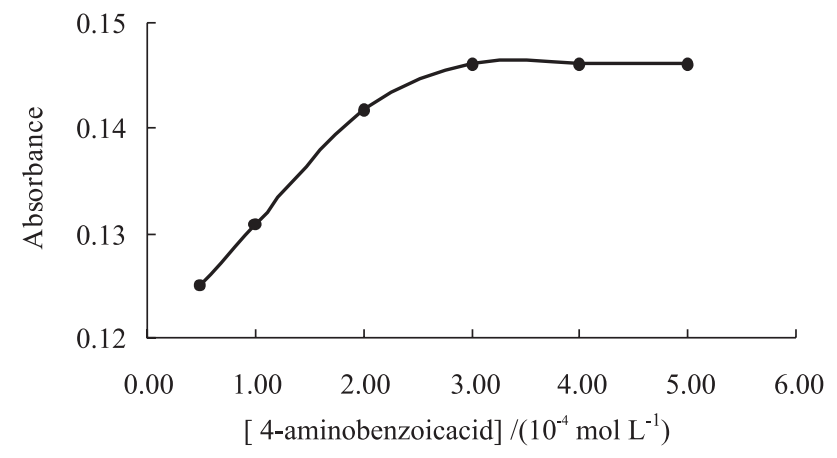

Figure 6. Effect of 4-aminobenzoic acid concentration on the oxidation reaction of dopamine. Conditions: Dopamine, $5.00 \mathrm{mg} \mathrm{L}^{-1}$; periodate, $3.0 \times 10^{-4} \mathrm{~mol} \mathrm{~L}^{-1} ; \mathrm{pH} 4$.

The effect of periodate concentration was studied in the range $0.1-4.0 \times 10^{-4} \mathrm{~mol} \mathrm{~L}^{-1}$. Figure 5 shows the results. The absorbance of the solution at $450 \mathrm{~nm}$ increased by increasing periodate concentration up to $2.0 \times 10^{-4} \mathrm{~mol}$ $\mathrm{L}^{-1}$ and remained constant at higher concentrations. Therefore, $3.0 \times 10^{-4} \mathrm{~mol} \mathrm{~L}^{-1}$ of periodate was selected as optimum concentration.

The effect of the 4-aminobenzoic acid concentration was studied in the range of $0.5-5.0 \times 10^{-4} \mathrm{~mol} \mathrm{~L}^{-1}$. Figure 6 shows the results and indicates that the absorbance increased at $450 \mathrm{~nm}$ by increasing 4-aminobenzoic acid concentration up to $3.0 \times 10^{-4} \mathrm{~mol} \mathrm{~L}^{-1}$ solution and remained constant at higher concentrations. Therefore 4.0 $\times 10^{-4} \mathrm{~mol} \mathrm{~L}^{-1}$ of 4 -aminobenzoic acid was selected.

\section{Analytical parameters}

From measurements made under the optimum conditions described above, the calibration graphs were linear in the range 0.20-18.00 $\mathrm{mg} \mathrm{L}^{-1}$ for dopamine, 0.10-20.00 $\mathrm{mg} \mathrm{L}^{-1}$ for methyldopa, $0.10-20.00 \mathrm{mg} \mathrm{L}^{-1}$ for levodopa and 0.10$13.00 \mathrm{mg} \mathrm{L}^{-1}$ for catechole. The calibration equations, linear
Table 3. Determination of catecholamines in pharmaceutical formulations

\begin{tabular}{lcccc}
\hline Analyte & Formulation & \multicolumn{3}{c}{ mg of analyte in a tablet or aliquot } \\
\cline { 3 - 5 } & & $\begin{array}{c}\text { Declared } \\
\text { amount }\end{array}$ & $\begin{array}{c}\text { Proposed } \\
\text { method }\end{array}$ & $\begin{array}{c}\text { Official } \\
\text { method }\end{array}$ \\
\hline Dopamine & Injection & 200 & $195.2 \pm 2.4$ & $195.2 \pm 2.4$ \\
Levodopa-C & Tablet & 100 & $98.9 \pm 1.1$ & $102.2 \pm 1.6$ \\
Methyldopa & Tablet & 250 & $244.0 \pm 2.4$ & $251.0 \pm 1.0$ \\
\hline
\end{tabular}

ranges and limit of detections are given in Table 1 . The limit of detection, defined as $\mathrm{C}_{\mathrm{L}}=3 \mathrm{~S}_{\mathrm{B}} / \mathrm{m},{ }^{17}$ where $\mathrm{C}_{\mathrm{L}}, \mathrm{S}_{\mathrm{B}}$ and $\mathrm{m}$ are the limit of detection, standard deviation, and the slope of the calibration graph, respectively.

To evaluate the accuracy and precision of the method, a series of independent synthetic samples $(n=7)$ containing $10.00 \mu \mathrm{g} \mathrm{mL}^{-1}$ catecholamines were analyzed by the proposed methods. The results are also given in Table 1.

\section{Interference studies}

The influence of various ions on the determination of $5.00 \mathrm{mg} \mathrm{L}^{-1}$ dopamine, methyldopa, levodopa and catechole by the proposed methods was studied. The results are given in Table 2. As Table 2 shows, most of the ions did not interfere even when present in 1000-fold excess over catecholamines. Sodium metabisulfate, and sodium chloride that is commonly present in the dopamine injection, and also commonly used excipients such as starch, talc, glucose, lactose, dextrose and magnesium stearate did not interfere.

\section{Application}

In order to evaluate the analytical applicability of the proposed method, it was applied to the determination of

Table 4. Recovery of catecholamines added to water samples

\begin{tabular}{lcccccc}
\hline & & $\begin{array}{c}\text { Added / } \\
\left(\mathrm{mg} \mathrm{L}^{-1}\right)\end{array}$ & $\begin{array}{c}\text { Found / } \\
\left(\mathrm{mg} \mathrm{L}^{-1}\right)\end{array}$ & $\begin{array}{c}\text { Recovery / } \\
(\%)\end{array}$ & $\begin{array}{c}\text { RSD } \\
(\mathrm{n}=5) /(\%)\end{array}$ & $\begin{array}{c}\text { Relative } \\
\text { error / (\%) }\end{array}$ \\
\hline Dopamine & Water & 1.00 & 1.02 & 102 & 1.17 & 2.00 \\
& & 10.00 & 9.88 & 9.88 & 1.51 & 1.20 \\
Methyldopa & Waste water & 10.00 & 9.64 & 96.4 & 1.32 & 3.61 \\
& Water & 0.50 & 0.49 & 98.0 & 2.17 & 2.00 \\
Levodopa & & 10.00 & 9.67 & 96.7 & 2.07 & 3.30 \\
& Waste water & 10.00 & 9.76 & 97.6 & 2.60 & 2.40 \\
Catechole & Water & 0.80 & 0.83 & 103.8 & 3.14 & 3.75 \\
& & 10.00 & 9.75 & 97.5 & 1.92 & 2.51 \\
& Waste water & 10.00 & 9.71 & 97.1 & 2.33 & 2.91 \\
& Water & 0.50 & 0.49 & 98.0 & 2.03 & 2.00 \\
\end{tabular}


Table 5. Comparison of visible spectrophotometric methods for the determination of some catecholamines

\begin{tabular}{|c|c|c|c|c|}
\hline Drug analyzed & Reagent & $\begin{array}{l}\text { Range of } \\
\text { determination / }\left(\mathrm{mg} \mathrm{L}^{-1}\right)\end{array}$ & Remarks & Reference \\
\hline $\mathrm{LDP}^{\mathrm{a}}, \mathrm{MDP}^{\mathrm{b}}, \mathrm{DPH}^{\mathrm{c}}, \mathrm{ADH}^{\mathrm{d}}$ & Periodate & $0.1-3.2$ & Narrow dynamic range & 19 \\
\hline PCL,DPH, LDP, MDP, ADH & $p$-Nitroaniline & $0.05-9.00$ & Narrow dynamic range & 20 \\
\hline LDP, DPH, PCL, ADH & $\begin{array}{l}\text { Nitration in the } \\
\text { presence of } \\
\text { molybdate or tungstate }\end{array}$ & Not reported & $\begin{array}{l}\text { Required } 50 \mathrm{~min} \text { to complete the reaction } \\
\text { readings are taken within } 20 \mathrm{~min}\end{array}$ & 21 \\
\hline DPH & Thiosemicarbazide & $1.0-8.0$ & Required $45 \mathrm{~min}$ to complete the reaction & 22 \\
\hline $\mathrm{PCL}^{\mathrm{e}}, \mathrm{DPH}, \mathrm{LDP}, \mathrm{MDP}$ & $\begin{array}{l}\text { Ionized in thepresence } \\
\text { of NBS }\end{array}$ & $0.8-17$ & Vitamin-C interferes seriously & 23 \\
\hline DPH, LDP & Meta periodate & $5.0-45$ & Heating at $60{ }^{\circ} \mathrm{C}$ in ethanol medium & 24 \\
\hline DPH, MDP & Polyphenol oxidase enzyme & Not reported & $\begin{array}{l}\mathrm{I}, \mathrm{SO}_{3}{ }^{2-} \text { interfere seriously, less sensitive and } \\
\text { complicated }\end{array}$ & 25 \\
\hline
\end{tabular}

alevodopa, ${ }^{\mathrm{b}}$ methyldopa, ${ }^{\mathrm{c} d o p a m i n e,}{ }^{\mathrm{d}}$ adrenaline, ${ }^{\mathrm{e}}$ pyrocatechol.

catecholamines in pharmaceutical preparations, tap water and waste water samples.

Catecholamines in injection and tablet formulations were determined by the proposed method. Catecholamines in injection formulations were determined after proper dilution of the sample with water. For determination of catecholamines in tablet, 20 tablets were weighed carefully and powdered. An accuratly weighed quantity of powder was shaken with water. After filtration and proper dilution of the solution the recommended procedure was followed. The results are given in Table 3. As Table 3 shows, there is a good agreement between the results obtained by the proposed method with those obtained by the official method. ${ }^{18}$

The water tested was found to be free from catecholamines and thus, synthetic samples were prepared by adding known amounts of catecholamines to the water samples. The results are given in Table 4 . As Table 4 shows the obtained recoveries were very close to $100 \%$. This indicates that the proposed method can be applied to the determination of catecholamines in such matrices.

\section{Comparison of the proposed method with other methods}

The proposed method was compared with some existing spectrophotometric methods. Table 5 clearly indicates that the proposed method provides wider dynamic range, more sensitive and free from interferences.

\section{Conclusions}

Catecholamines are oxidized to their corresponding $o$-quinones. The quinones are then attacked by 4-aminobenzoic acid to form $o$-benzoquinone derivatives. The $o$-benzoquinone derivatives can be used to the spectrophotometric determination of catecholamines by spectrophotometric method. The proposed method is found to be simpler and more sensitive than any reported methods on catecholamines. The statistical parameters and the recovery study data clearly indicate the reproducibility and accuracy of the method. The method can be applied to the accurate determination of catecholamines in pharmaceutical preparations and water samples.

\section{References}

1. George, B. K.; Goodman, L. S. The Pharmacological Basis of Therapeutics, $3^{\text {rd }}$ ed., The Macmillan Company: New York, 1965, p. 427.

2. Brandsteterova, E.; Kubalec, P.; Krajnak, K.; Skacani, I.; Neoplasma 1996, 43,107.

3. Hollenbach, E.; Schulz, C.; Lehnert, H.; Life Sci. 1998, 63, 737.

4. Lakshmana, M. K.; Raju, T. R.; Anal. Biochem. 1997, 246, 166.

5. Sharma, C.; Mohanty, S.; Kumar, S.; Rao, N. G.; Analyst 1996, 121, 19631.

6. Chang, H. T.; Yeung, E. S.; Anal. Chem. 1995, 67, 1079.

7. Ragab, G. H.; Nohta, H.; Kai, M.; Ohkura, Y.; Zaitsu, K.; J. Pharm. Biomed. Anal. 1995, 13, 645.

8. Unceta, N.; Rodriguez, E.; de Balugera, Z. G.; Sampedro, C.; Goicolea, M. A.; Barrondo, S.; Salles, J.; Barrio, R. J.; Anal. Chim. Acta 2001, 441, 211.

9. Ricebery, L. J.; Vanuis, H. V.; Levin, L.; Anal. Biochem. 1974, $60,551$.

10. Hu, S.; Li, P.B.; Cheng, J. K.; Fenxi. Shiyanshi. 1996, 15, 1.

11. Aman, T.; Khan, I. U.; Aslam, N.; Ahmed, I.; Anal. Lett. 1998, 31, 1007.

12. Kothari, Y. K.; Srinivasalu, K.; Asian J. Chem. 1989, 1, 42.

13. Biryuk, A.; Petrenko, V. V.; Zorya, B. P.; Farm. Zh. (Kiev) 1992, 2,57 .

14. Mohamed, W. I.; Salem, F. B.; Anal. Lett. 1984, 17, 191. 
15. Afkhami, A.; Nematollahi, D.; Khalafi, L.; Rafiee, M.; Int. J. Chem. Kinet. 2005, 37, 17.

16. Afkhami, A.; Nematollahi, D.; Madrakian, T.; Khalafi, L.; Electrochim. Acta 2005, 50, 5633.

17. Thomsen, V; Schatzlein, D; Mercuro, D; Spectroscopy 2003, 18, 112

18. United States Pharmacopeia, $23^{\text {rd }}$ review, Twinbrook Parkway: Rockville, 1995.

19. Afkhami, A.; Khatami, H.; J. Anal. Chem. 2003, 58, 135.

20. Nagaraja, P.; Vasantha, R. A.; Sunitha, K. R.; J. Pharm. Biomed. Anal. 2001, 25, 417.
21. Barnum, D. W.; Anal. Chim. Acta 1977, 89, 157.

22. EL-Kommos, M. E.; Journal De Pharmcie De Belgic 1987, 42, 371.

23. Nagaraja, P.; Murthy, K. C. S.; Yathirajan, H. S.; Mohan, B. M.; Indian J. Pharm. Sci. 1998, 60, 99.

24. EL-Kommos, M. E.; Mohamed, F. A.; Khedr., A. S.; J. Assoc. Off. Anal. Chem. 1990, 73, 516.

25. Da Cruz Vieira, I.; Fatibello- Filho, O.; Talanta 1998, 46, 559.

Received: February 20, 2006

Published on the web: August 22, 2006 